\title{
HOUSEHOLDS AND LABOUR MIGRATION IN POST-APARTHEID SOUTH AFRICA
}

\author{
D Posel ${ }^{*}$
}

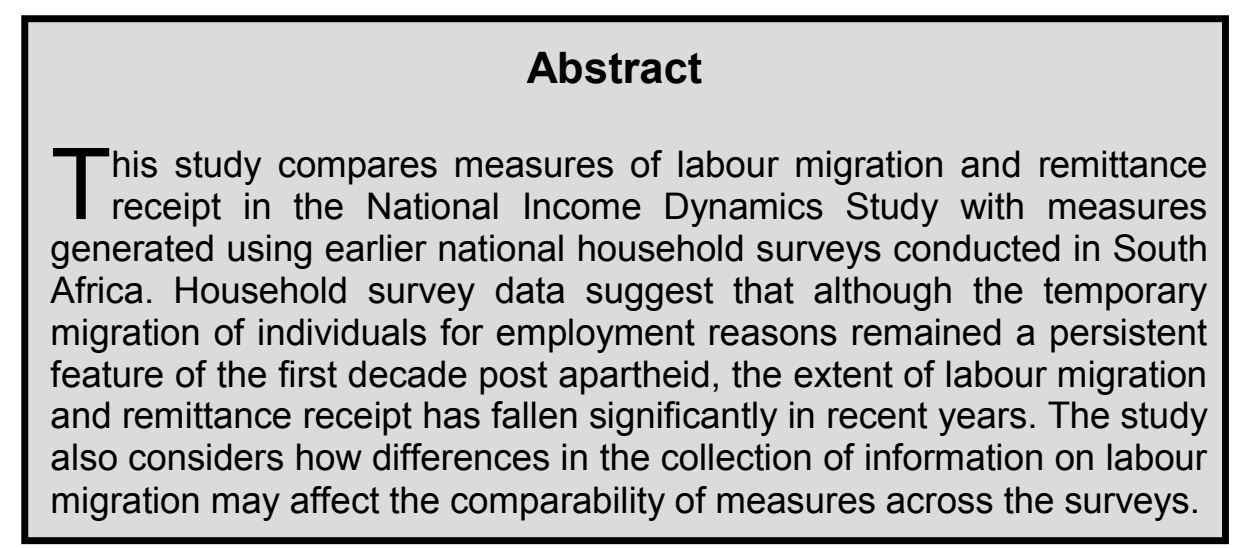

\section{Introduction}

Migration, at the broadest level, involves the movement of individuals or households across space and a change in the place of residence. This migration may be permanent because it implies a long-term change of residency, or it may be temporary in that migrants retain membership in their household (or country) of origin, to which they expect to return at some point in the future.

Historically, much of the labour migration that occurred within South Africa involved the temporary migration of individuals to places of employment. A range of restrictions prevented African labour force participants from migrating with their families or from settling permanently in urban areas. These restrictions, together with the contractual nature of employment, gave rise to patterns of circular or oscillating migration. Many labour migrants would retain a base in the household from which they had migrated, to which they would return each year and which was their 'permanent' home. Remittance transfers sent by migrant workers in turn were an integral source of income for the household of origin.

Restrictions on the movement and settlement of people in South Africa were lifted in 1986. However, research based on nationally representative household survey data for the period 1993 to 2002 suggests that patterns of circular labour migration

\footnotetext{
* School of Development Studies, University of KwaZulu-Natal, Durban 4001, Republic of South Africa. The author acknowledges financial support for this paper from the Programme to Support Propoor Policy Development in the South African Presidency.

Email: posel@ukzn.ac.za
} 
continued in the first post-apartheid decade and that a significant proportion of households remained reliant on remittances sent by migrant workers (Posel \& Casale 2003, Posel \& Casale 2006). Between 1993 and 2002, an increasing number of households particularly in rural areas reported that they contained at least one household member who was away for a period of time each year to work, or to look for work. Furthermore, the majority of these households reported receiving remittance transfers from migrant household members. These findings were corroborated by other studies using regionally specific data. A high prevalence of temporary labour migration through the $1990 \mathrm{~s}$, for example, is documented in African households sampled in the Agincourt Demographic Surveillance Site (see for example Collinson et al., 2006; Collinson et al., 2007).

In the post-apartheid period, where the permanent migration of families to urban areas is no longer prohibited, the persistence of temporary labour migration is perhaps unexpected. However, one explanation may simply be that deeply entrenched migration patterns take time to change, and that the temporary migration of individuals will be replaced over time by the permanent settlement of households. What is being identified as "temporary" or "circular" labour migration through survey instruments may in fact be the precursor to the permanent outmigration of individuals and their families. ${ }^{1}$

A key objective of this paper is to update trends in labour migration in South Africa, using data from the first wave of the National Income Dynamics Study (NIDS) conducted in 2008. Household surveys in South Africa have not consistently collected information on labour migrants and remittance transfers, and the information which has been collected has often been incomplete. Furthermore, after 2005, none of the official national household surveys included any questions which identified migrant workers or the households from which this migration occurred. In contrast, NIDS collects detailed information on the characteristics of labour migrants and the value of income remitted, and it offers the means to investigate migration patterns in recent years.

However, it must also be recognised that the way in which the household is defined, and therefore how labour migration is identified, differs considerably between NIDS and the official national household surveys, a difference which may compromise the comparability of data over time. A further objective of this study, therefore, is to compare how information on the household and on labour migration specifically, is collected in NIDS and in other surveys.

The paper is structured as follows. The next section considers the definition of the household, and in particular, the distinction between resident and non-resident or absent household members. A key reason why individuals may be absent from a

\footnotetext{
${ }_{1}$ For example, research which investigated return migration from the Western Cape to the Eastern Cape, found that return migration to the Eastern Cape may be low or becoming "less common" (see respectively Bekker's (2001) study based on 660 African and Coloured households in the Eastern and Western Cape, and van der Berg et al.'s (2004) study of the 1996 Census). Although many individuals may have migrated with the intention of returning to their household of origin, this desire weakened as duration in destination areas increased.
} 
household for much of the year is because they are labour migrants. The third section therefore looks specifically at households which report migrant workers as absent household members. Section four describes inter-household transfers received by households, and it considers the relationship between households that report transfers and households that report migrant workers. The last section summarises the main similarities and differences between NIDS and other household surveys in South Africa and outlines the key findings of the study.

\section{Households with absent members}

Households in South Africa are more complex formations than households typically found in developed countries. In particular, individuals can be members of more than one household, and they may be considered to be part of a household even if they are not resident in the household for much of the year.

Most national household surveys in South Africa have not identified, and therefore collected information on, all absent household members. Rather, these household surveys have imposed a "strict" residency requirement in defining household membership. For example, the household surveys conducted by the official statistical agency in South Africa (such as the October Household Surveys (OHS), the Labour Force Surveys (LFS) and the General Household Surveys (GHS)), collect information only on household members who are usually resident in the household for at least four nights of the week.

In contrast, NIDS adopts a broader residency requirement which recognises fluidity in household composition. Individuals can be identified as household members even if they had resided in the household for only 15 days of the previous year. This definition of household membership mirrors that adopted in the Project for Statistics on Living Standards and Development (PSLSD), the first nationally representative household survey in South Africa, also conducted by the Southern Africa Labour and Development Research Unit in 1993.

In this section, I compare the extent of "absent" household membership in South Africa, captured in the PSLSD and in NIDS. Absent household members are individuals who are reported as household members but who:

- do not usually reside at least four nights of the week in the household; ${ }^{2}$ or

- $\quad$ are absent from the household for at least a month a year to work or to look for work, or because they are in prison or in school; or

- are away from the household for more than three months of the year for other reasons.

\footnotetext{
${ }^{2}$ The distinction between an absent household member and a resident household member is relatively consistent across NIDS and the PSLSD. One small difference is that the PSLSD asks whether individuals have been resident in the household for the last 15 days out of 30 days; whereas NIDS asks whether individuals "usually reside here at least four nights a week". The question on residency in NIDS is consistent with how residency is defined in the official household surveys conducted by Statistics South Africa.
} 
Table 1 describes measures of households with absent adult members across NIDS and the PSLSD. The data suggest that from 1993 to 2008, there has been a significant fall in the percentage of households that report non-resident household members, from approximately 24 percent of households in 1993 to 18 percent in 2008. However, both surveys identify similar patterns in absence across households: African ${ }^{3}$ households are more likely than other households to report absent household members; and African households in rural areas are the most likely to contain non-resident members. In 1993 and 2008, 39 percent and 30 percent respectively of African households in rural areas reported at least one adult as a non-resident member of the household.

Table 1: Households with absent adult members, 1993 and 2008

\begin{tabular}{|c|c|c|}
\hline Households with absent adult member(s) & $\begin{array}{c}\text { PSLSD } \\
1993 \\
\end{array}$ & $\begin{array}{c}\text { NIDS } \\
2008 \\
\end{array}$ \\
\hline & \multicolumn{2}{|c|}{ Unweighted } \\
\hline Number: & & \\
\hline All households & 2189 & 1595 \\
\hline African households & 1917 & 1412 \\
\hline African rural households & 1654 & 1042 \\
\hline \multicolumn{3}{|l|}{ Proportion: } \\
\hline All households & $\begin{array}{c}0,25 \\
(0,00)\end{array}$ & $\begin{array}{c}0,22 \\
(0,00)\end{array}$ \\
\hline African households & $\begin{array}{c}0,29 \\
(0,01)\end{array}$ & $\begin{array}{c}0,25 \\
(0,01)\end{array}$ \\
\hline \multirow[t]{2}{*}{ African rural households } & $\begin{array}{r}0,39 \\
(0,01) \\
\end{array}$ & $\begin{array}{c}0,33 \\
(0,01) \\
\end{array}$ \\
\hline & \multicolumn{2}{|c|}{ Weighted } \\
\hline \multicolumn{3}{|l|}{ Number: } \\
\hline All households & $\begin{array}{c}2015009 \\
(37623)\end{array}$ & $\begin{array}{c}2478440 \\
(91993)\end{array}$ \\
\hline African households & $\begin{array}{c}1731385 \\
(33333)\end{array}$ & $\begin{array}{c}2105152 \\
(72392)\end{array}$ \\
\hline African rural households & $\begin{array}{c}1488519 \\
(28605)\end{array}$ & $\begin{array}{c}1326908 \\
(48217)\end{array}$ \\
\hline \multicolumn{3}{|l|}{ Proportion: } \\
\hline All households & $\begin{array}{c}0,24 \\
(0,00)\end{array}$ & $\begin{array}{c}0,18 \\
(0,01)\end{array}$ \\
\hline African households & $\begin{array}{c}0,28 \\
(0,01)\end{array}$ & $\begin{array}{c}0,20 \\
(0,01)\end{array}$ \\
\hline African rural households & $\begin{array}{c}0,39 \\
(0,01)\end{array}$ & $\begin{array}{c}0,30 \\
(0,01)\end{array}$ \\
\hline
\end{tabular}

Source: Own calculations, PSLSD 1993 and NIDS 2008.

Notes: Adults are all individuals older than 15 years. Where age information is missing, adults are identified as individuals who are married, widowed or divorced, or who have completed at least a grade 11 education. Rural in NIDS comprises tribal areas, and rural formal and informal areas. Standard errors are in parentheses.

\footnotetext{
${ }^{3}$ Information on race is not collected in the household roster questionnaire in NIDS. To identify the race of a household, I mapped race information collected in the adult questionnaire onto all households. There are a small number of mixed race households. In the estimates provided here, a household is identified as an "African" household if it contained at least one resident African adult member.
} 
Table 2 summarises why adults are absent from the household. ${ }^{4}$ In both surveys, the majority of household members are identified as absent for employment reasons. However, the proportion of adults absent from the household because they are working elsewhere falls considerably from 1993 to 2008 (from 0,77 to 0,59 ). An increasing proportion of adults are reported as absent for education reasons $(0,13$ in 2008 compared to 0,10 in 1993); and there is a dramatic rise in the share of adults who are reported as household members but who are identified as "living elsewhere" (from 0,02 to 0,17 ).

Individuals who are absent from the household because they are working or looking for work in South Africa are typically referred to as migrant workers. One possible explanation for why migrant workers form a smaller share of all absent household members in 2008 (and more generally why the proportion of households with absent members has fallen) may be that migrant workers are settling at their places of employment. In this case, they could either be reported as absent household members but the reason for absence is given as "living elsewhere", or they are not retaining membership in their household of origin. The next section explores trends in labour migration further.

Table 2: Reasons for absence among adults, 1993 and 2008

\begin{tabular}{lcc}
\hline Proportion of adults absent because of: & PSLSD & NIDS \\
& $\mathbf{1 9 9 3}$ & $\mathbf{2 0 0 8}$ \\
\hline Employment reasons (work/look for work) & 0,765 & 0,590 \\
& $(0,007)$ & $(0,015)$ \\
Education & 0,097 & 0,132 \\
& $(0,005)$ & $(0,010)$ \\
Personal reasons & 0,077 & 0,073 \\
& $(0,005)$ & $(0,008)$ \\
Business reasons & 0,004 & 0,005 \\
Prison & $(0,001)$ & $(0,002)$ \\
& 0,002 & 0,012 \\
Hospital & $(0,001)$ & $(0,003)$ \\
Living elsewhere & 0,011 & 0,008 \\
& $(0,002)$ & $(0,003)$ \\
Violence/political problems & 0,021 & 0,174 \\
& $(0,002)$ & $(0,012)$ \\
Other & 0,002 & 0,002 \\
& $(0,001)$ & $(0,002)$ \\
& 0,015 & 0,004 \\
& $(0,002)$ & $(0,001)$ \\
\hline
\end{tabular}

Source: Own calculations, PSLSD 1993 and NIDS 2008.

Notes: The data are weighted. Personal reasons include: visiting spouse, family or friends; and away on vacation. Standard errors are in parentheses.

\footnotetext{
${ }^{4}$ The question on reasons for absence is almost identical across the two surveys, except that the PSLSD includes an option for "national service". For comparability purposes, national service has been included under "other" reasons in Table 2.
} 


\section{Labour migration}

One of the distinguishing characteristics of apartheid South Africa was the ways in which restrictions on settlement and employment divided families across space. These formal restrictions were removed in the late $1980 \mathrm{~s}$, but available data suggest that individuals continue to migrate "temporarily" to places of employment, retaining membership in their household of origin.

Although most national household surveys in South Africa do not collect information on all non-resident household members, some surveys have included a separate module on migrant workers specifically. ${ }^{5}$ Migrant workers typically are identified in these surveys as individuals who are regarded as members of the household but who are away for at least a month of the year to work or to look for work. In NIDS (and in the PSLSD), migrant workers can be defined similarly through the household roster questionnaire, as individuals who are members of the household but who are absent for a month or more in the year for employment reasons. This section compares measures of labour migration estimated in NIDS with measures derived from other household surveys in South Africa.

Table 3 describes an increase in the number of households reporting migrant workers from 1993 to 2002, with the extent of labour migration then remaining relatively unchanged to 2005, but falling substantially in 2008. In 2005, approximately two million households (or about 16 percent of all households) reported migrant workers as household members; by 2008 , this had fallen to approximately 1,5 million households (or 11 percent of all households).

The decline in measures of labour migration in NIDS coincides with an increase in the proportion of absent household members whose reason for absence is given as "living elsewhere". However, even if all these absent household members are recoded as labour migrants, estimates of labour migration would remain significantly lower in NIDS than in the other household surveys: 16 percent of all African households, and 25 percent of rural African households, would be identified as containing labour migrant members in 2008.

Although there are large differences in measures of labour migration between NIDS and the other household surveys, patterns of labour migration are consistent. The vast majority of households which report migrant workers are African households. Furthermore, most labour migration originates from African households located in rural areas where there are limited employment and income-generating opportunities (May and Rogerson, 2000; Bhorat and Leibbrandt, 2001; Aliber, 2003).

\footnotetext{
${ }^{5}$ These surveys include the OHSs $(1996$ - 1999) and the September LFSs $(2002-2005)$.
} 
Table 3: The extent of temporary labour migration across households, 19932008

\begin{tabular}{|c|c|c|c|c|c|c|}
\hline $\begin{array}{l}\text { Households with } \\
\text { migrant worker(s) }\end{array}$ & $\begin{array}{c}\text { PSLSD } \\
1993 \\
\end{array}$ & $\begin{array}{l}\text { OHS } \\
1999 \\
\end{array}$ & $\begin{array}{l}\text { LFS } \\
2002 \\
\end{array}$ & $\begin{array}{l}\text { LFS } \\
2004\end{array}$ & $\begin{array}{l}\text { LFS } \\
2005\end{array}$ & $\begin{array}{l}\text { NIDS } \\
2008\end{array}$ \\
\hline \multicolumn{7}{|l|}{ Number: } \\
\hline All households & $\begin{array}{c}1604104 \\
(34394)\end{array}$ & $\begin{array}{c}1780779 \\
(27644)\end{array}$ & $\begin{array}{c}2059737 \\
(32460)\end{array}$ & $\begin{array}{c}2033005 \\
(33618)\end{array}$ & $\begin{array}{c}1993015 \\
(32653)\end{array}$ & $\begin{array}{c}1495134 \\
(71656)\end{array}$ \\
\hline African households & $\begin{array}{c}1443232 \\
(31423)\end{array}$ & $\begin{array}{c}1722400 \\
(26700)\end{array}$ & $\begin{array}{c}1980792 \\
(31247)\end{array}$ & $\begin{array}{c}1983709 \\
(32768)\end{array}$ & $\begin{array}{c}1929645 \\
(31655)\end{array}$ & $\begin{array}{c}1331161 \\
(57295)\end{array}$ \\
\hline African rural households & $\begin{array}{c}1295763 \\
(27812)\end{array}$ & $\begin{array}{c}1418364 \\
(25030)\end{array}$ & $\begin{array}{c}1636161 \\
(26759)\end{array}$ & $\begin{array}{c}1593535 \\
(28084)\end{array}$ & $\begin{array}{c}1529584 \\
(26546)\end{array}$ & $\begin{array}{l}960452 \\
(43215)\end{array}$ \\
\hline \multicolumn{7}{|l|}{ Percentage: } \\
\hline All households & $\begin{array}{l}18,8 \\
(0,41)\end{array}$ & $\begin{array}{l}16,6 \\
(0,25)\end{array}$ & $\begin{array}{l}17,3 \\
(0,26)\end{array}$ & $\begin{array}{l}16,2 \\
(0,27)\end{array}$ & $\begin{array}{l}15,7 \\
(0,26)\end{array}$ & $\begin{array}{l}10,9 \\
(0,52)\end{array}$ \\
\hline African households & $\begin{array}{l}23,7 \\
(0,52)\end{array}$ & $\begin{array}{l}21,6 \\
(0,33)\end{array}$ & $\begin{array}{l}22,1 \\
(0,35)\end{array}$ & $\begin{array}{l}20,5 \\
(0,34)\end{array}$ & $\begin{array}{l}19,7 \\
(0,33)\end{array}$ & $\begin{array}{l}12,6 \\
(0,55)\end{array}$ \\
\hline Rural African households & $\begin{array}{l}33,8 \\
(0,73)\end{array}$ & $\begin{array}{l}35,8 \\
(0,54)\end{array}$ & $\begin{array}{l}36,9 \\
(0,58)\end{array}$ & $\begin{array}{l}36,9 \\
(0,59)\end{array}$ & $\begin{array}{l}36,0 \\
(0,59)\end{array}$ & $\begin{array}{l}21,8 \\
(0,96)\end{array}$ \\
\hline
\end{tabular}

Source: Own calculations: PSLSD 1993; OHS 1999; September LFSs 2002, 2004, 2005; NIDS 2008.

Notes: The data in the table are weighted. Migrants are aged 15 years and older. Standard errors are in parentheses.

Table 4 compares the characteristics of African migrant workers over the years. In those OHSs and LFSs where a separate module on migrant workers is included in the survey questionnaire, only a limited number of questions are asked about migrant workers. In the OHSs, for example, no information is collected on the education of migrant workers whereas in the LFSs, no question identifying the age of migrants is included. A distinguishing feature of NIDS is that the same basic demographic information is collected on all household members, whether resident or absent.

Across all the surveys, the demographic characteristics of labour migrants are largely consistent. The majority of labour migrants are male although there is some suggestion that women form a growing share of labour migrants, rising from 29 percent in 1993 to 37 percent in 2008. Since 1993, labour migrants also appear to have more education with a jump particularly from 1993 to 2002, and then from 2005 to 2008 , in the proportion of labour migrants reported as holding at least a matric education. In many developing countries, the typical labour migrant is a young unmarried son or daughter of the household head (cf. Rigg 2006, Chant and Mcllwane 2009). In South Africa, however, the average age migrant workers is approximately 35 years and a sizeable share of migrant workers are married, leaving their partners and children 'behind' in the household from which they migrate. 
Table 4: Characteristics of African migrant workers (15 years and older)

\begin{tabular}{|c|c|c|c|c|c|c|}
\hline & $\begin{array}{c}\text { PSLSD } \\
1993\end{array}$ & $\begin{array}{l}\text { OHS } \\
1999\end{array}$ & $\begin{array}{l}\text { LFS } \\
2002\end{array}$ & $\begin{array}{l}\text { LFS } \\
2004\end{array}$ & $\begin{array}{l}\text { LFS } \\
2005\end{array}$ & $\begin{array}{c}\text { NIDS } \\
2008\end{array}$ \\
\hline Female & $\begin{array}{l}0,29 \\
(0,01)\end{array}$ & $\begin{array}{l}0,34 \\
(0,01)\end{array}$ & $\begin{array}{l}0,37 \\
(0,01)\end{array}$ & $\begin{array}{l}0,36 \\
(0,01)\end{array}$ & $\begin{array}{l}0,36 \\
(0,01)\end{array}$ & $\begin{array}{l}0,37 \\
(0,02)\end{array}$ \\
\hline Age & $\begin{array}{l}34,80 \\
(0,26)\end{array}$ & $\begin{array}{l}36,58 \\
(0,14)\end{array}$ & -- & -- & -- & $\begin{array}{l}35,23 \\
(0,43)\end{array}$ \\
\hline Years of schooling & $\begin{array}{l}6,83 \\
(0,09)\end{array}$ & -- & $\begin{array}{l}8,23 \\
(0,05)\end{array}$ & $\begin{array}{l}8,47 \\
(0,04)\end{array}$ & $\begin{array}{l}8,52 \\
(0,04)\end{array}$ & $\begin{array}{l}9,11 \\
(0,14)\end{array}$ \\
\hline At least a matric (Grade 12) & $\begin{array}{l}0,17 \\
(0,01)\end{array}$ & -- & $\begin{array}{l}0,29 \\
(0,01)\end{array}$ & $\begin{array}{l}0,31 \\
(0,01)\end{array}$ & $\begin{array}{l}0,31 \\
(0,01)\end{array}$ & $\begin{array}{l}0,35 \\
(0,02)\end{array}$ \\
\hline Married & -- & -- & $\begin{array}{l}0,37 \\
(0,01)\end{array}$ & $\begin{array}{l}0,34 \\
(0,01)\end{array}$ & $\begin{array}{l}0,32 \\
(0,01)\end{array}$ & $\begin{array}{l}0,35 \\
(0,02)\end{array}$ \\
\hline (unweighted sample) & 2557 & 5746 & 6862 & 7998 & 7931 & 1205 \\
\hline
\end{tabular}

Source: Own calculations: PSLSD 1993; OHS 1999; September LFSs 2002, 2004, 2005; NIDS 2008.

Notes: Married includes living together. The 1999 OHS collected information on the age of the migrant worker but not on the migrant's education or marital status. The LFSs, in contrast, collected information on the education and marital status, but not on the age, of the migrant worker. Standard errors are in parentheses.

\section{Remittances}

Many households in South Africa rely not only on income generated by resident household members, but also on inter-household transfers of income. An important type of transfer is remittance income, sent by migrant workers to (members of) their household of origin.

In most surveys where it is possible to identify migrant workers, information is also collected on the value of remittances received from these migrants. However, there are important differences in how questions on remittance transfers are included in the survey instrument. In the OHSs and the LFSs, questions on remittance receipt are tied to questions on migrant workers. Only those households with migrant workers can report on income transfers received. In NIDS and the PSLSD, in contrast, questions on remittances, and inter-household transfers more generally, are asked in a different part of the questionnaire. Consequently, information is collected not only on income transfers received from migrant workers, but also on contributions received from other individuals, including absent household members who are not identified as migrant workers, and individuals who are not household members (for example in the case of child maintenance payments).

In this section, I first compare information collected in NIDS and in the PSLSD on all income transfers received in households, and I then look specifically at estimates of remittances in migrant households, comparing measures in NIDS also to those in the 1999 OHS and selected LFSs.

Table 5 identifies the number and proportion of households which report positive values for income (cash or in-kind) transfers received from individuals who are not resident household members, and the average monthly household value of these 
contributions ${ }^{6}$ in 1993 and 2008. The data describe a large fall in the proportion of all households receiving income transfers in 2008. In 1993, approximately 23 percent (24 percent unweighted) of all households reported positive income transfers from "absent members of the household or from any other person". In 2008 , this had fallen to 15 percent (16 percent unweighted).

The NIDS data are distinctive also because they show a large mismatch between households that report positive income transfers and households that report migrant workers. Table 5 illustrates that only 28 percent (or 24 percent unweighted) of all households receiving income contributions are identified as "migrant households" (households which report migrants workers as absent household members). In surveys where remittance questions are tied to migrant questions, this kind of mismatch is not possible. However, the PSLSD adopted the same approach to collecting information on income transfers as NIDS, and here the relationship between households that receive transfers and households with migrant workers is far stronger: in 1993, approximately 61 percent of all households receiving income transfers are also households that report migrant workers.

Table 5. Income transfers received, 1993 and 2008

\begin{tabular}{|c|c|c|}
\hline & $\begin{array}{l}\text { PSLSD } \\
1993 \\
\end{array}$ & $\begin{array}{l}\text { NIDS } \\
2008\end{array}$ \\
\hline & \multicolumn{2}{|c|}{ Unweighted } \\
\hline Number of households receiving contributions & 2115 & 1186 \\
\hline Proportion of all households receiving transfers & $\begin{array}{c}0,24 \\
(0,01)\end{array}$ & $\begin{array}{c}0,16 \\
(0,00)\end{array}$ \\
\hline $\begin{array}{l}\text { Average household monthly nominal value of transfers } \\
\text { (Rands) }\end{array}$ & $\begin{array}{r}255,05 \\
(5,68)\end{array}$ & $\begin{array}{l}552,32 \\
(32,11)\end{array}$ \\
\hline $\begin{array}{l}\text { Average household monthly real value of transfers (Rands, } \\
2000 \text { prices) }\end{array}$ & $\begin{array}{l}416,75 \\
(9,28)\end{array}$ & $\begin{array}{l}345,20 \\
(20,07)\end{array}$ \\
\hline $\begin{array}{l}\text { Number of households receiving transfers which are also } \\
\text { migrant households }\end{array}$ & 1304 & 287 \\
\hline \multirow[t]{2}{*}{$\begin{array}{l}\text { Proportion of households receiving transfers which are } \\
\text { also migrant households }\end{array}$} & $\begin{array}{c}0,62 \\
(0,01)\end{array}$ & $\begin{array}{c}0,24 \\
(0,01)\end{array}$ \\
\hline & \multicolumn{2}{|c|}{ Weighted } \\
\hline Number of households receiving transfers & $\begin{array}{c}1932640 \\
(36845)\end{array}$ & $\begin{array}{l}2112171 \\
(92265)\end{array}$ \\
\hline Proportion of all households receiving transfers & $\begin{array}{l}0,23 \\
(0,00)\end{array}$ & $\begin{array}{l}0,15 \\
(0,01)\end{array}$ \\
\hline $\begin{array}{l}\text { Average household monthly nominal value of transfers } \\
\text { (Rands) }\end{array}$ & $\begin{array}{r}256,94 \\
(5,87)\end{array}$ & $\begin{array}{l}740,21 \\
(83,91)\end{array}$ \\
\hline $\begin{array}{l}\text { Average household monthly real value of transfers (Rands, } \\
2000 \text { prices) }\end{array}$ & $\begin{array}{l}419,83 \\
(9,59)\end{array}$ & $\begin{array}{l}462,63 \\
(52,44)\end{array}$ \\
\hline $\begin{array}{l}\text { Number of households receiving transfers which are also } \\
\text { migrant households }\end{array}$ & $\begin{array}{l}1170754 \\
(20170)\end{array}$ & $\begin{array}{l}422316 \\
(32602)\end{array}$ \\
\hline $\begin{array}{l}\text { Proportion of households receiving transfers which are } \\
\text { also migrant households }\end{array}$ & $\begin{array}{c}0,61 \\
(0,01) \\
\end{array}$ & $\begin{array}{c}0,28 \\
(0,02) \\
\end{array}$ \\
\hline \multicolumn{3}{|c|}{$\begin{array}{l}\text { Source: Own calculations, PSLSD } 1993 \text { and NIDS } 2008 \text {. } \\
\text { Notes: A household is identified as receiving transfers only if positive income values for transfers are } \\
\text { reported. Reported remittance values are conditional on remittances being received. A migration household is } \\
\text { a household which includes an individual who is absent from the household for employment reasons. } \\
\text { Nominal income has been converted to real income in } 2000 \text { prices using the CPI index published by Statistics } \\
\text { South Africa. Standard errors are in parentheses. }\end{array}$} \\
\hline
\end{tabular}

\footnotetext{
${ }^{6}$ The monthly value of income transfers is calculated as the monthly average of total annual transfers received by the household, in both cash and in-kind.
} 
Table 6 explores further the extent of remittance receipt in African migrant households specifically, looking also at other household surveys conducted between 1993 and 2008. Until 2005 (the last year of the LFS for which remittance data are available), the majority of African households with migrant workers also reported positive values for remittance income. However, estimates of remittance receipt in the NIDS data differ sharply. From 2002 to 2005, the percentage of migrant households receiving remittances remained stable at about 76 percent; but in 2008, only 31 percent of migrant households reported non-zero remittance income. A far smaller share of migrant households therefore is identified as receiving remittances in 2008, in comparison to the other years, (although differences in the monthly household value of these remittances, conditional on positive remittances, are less marked).

Table 6: Remittances received in African migrant households

\begin{tabular}{|c|c|c|c|c|c|c|}
\hline & $\begin{array}{c}\text { PSLSD } \\
1993\end{array}$ & $\begin{array}{l}\text { OHS } \\
1999\end{array}$ & $\begin{array}{r}\text { LFS } \\
2002 \\
\end{array}$ & $\begin{array}{r}\text { LFS } \\
2004 \\
\end{array}$ & $\begin{array}{l}\text { LFS } \\
2005\end{array}$ & $\begin{array}{l}\text { NIDS } \\
2008\end{array}$ \\
\hline & \multicolumn{6}{|c|}{ All African migrant households } \\
\hline $\begin{array}{l}\text { Percentage of migrant households } \\
\text { receiving remittances }\end{array}$ & $\begin{array}{l}78,24 \\
(1,04)\end{array}$ & $\begin{array}{l}85,12 \\
(0,62)\end{array}$ & $\begin{array}{l}76,99 \\
(0,71)\end{array}$ & $\begin{array}{l}76,15 \\
(0,77)\end{array}$ & $\begin{array}{l}76,38 \\
(0,74)\end{array}$ & $\begin{array}{l}31,00 \\
(2,14)\end{array}$ \\
\hline $\begin{array}{l}\text { Average monthly nominal value of total } \\
\text { remittances received by the household } \\
\text { (Rands) }\end{array}$ & $\begin{array}{l}279,21 \\
(6,73)\end{array}$ & -- & $\begin{array}{l}344,08 \\
(7,43)\end{array}$ & $\begin{array}{l}479,90 \\
(13,50)\end{array}$ & $\begin{array}{l}508,18 \\
(22,77)\end{array}$ & $\begin{array}{l}561,01 \\
(51,44)\end{array}$ \\
\hline \multirow[t]{2}{*}{$\begin{array}{l}\text { Average monthly real value of total } \\
\text { remittances received by the household } \\
\text { (Rands, } 2000 \text { prices) }\end{array}$} & $\begin{array}{l}456,23 \\
(11,00)\end{array}$ & -- & $\begin{array}{l}298,17 \\
(6,43)\end{array}$ & $\begin{array}{l}387,64 \\
(11,22)\end{array}$ & $\begin{array}{l}397,01 \\
(17,79)\end{array}$ & $\begin{array}{l}350,63 \\
(32,15)\end{array}$ \\
\hline & \multicolumn{6}{|c|}{ Rural African migrant households } \\
\hline $\begin{array}{l}\text { Percentage of migrant households } \\
\text { receiving remittances }\end{array}$ & $\begin{array}{l}79,10 \\
(1,08)\end{array}$ & $\begin{array}{l}85,39 \\
(0,69)\end{array}$ & $\begin{array}{l}77,15 \\
(0,79)\end{array}$ & $\begin{array}{l}74,61 \\
(0,89)\end{array}$ & $\begin{array}{l}75,33 \\
(0,83)\end{array}$ & $\begin{array}{l}30,84 \\
(2,18)\end{array}$ \\
\hline $\begin{array}{l}\text { Average monthly nominal value of total } \\
\text { remittances received by the household } \\
\text { (Rands) }\end{array}$ & $\begin{array}{l}251,10 \\
(5,87)\end{array}$ & -- & $\begin{array}{l}340,53 \\
(8,05)\end{array}$ & $\begin{array}{l}452,29 \\
(11,91)\end{array}$ & $\begin{array}{l}445,89 \\
(11,35)\end{array}$ & $\begin{array}{l}585,15 \\
(45,02)\end{array}$ \\
\hline $\begin{array}{l}\text { Average monthly real value of total } \\
\text { remittances received by the household } \\
\text { (Rands, } 2000 \text { prices) }\end{array}$ & $\begin{array}{l}458,43 \\
(11,57)\end{array}$ & -- & $\begin{array}{l}295,09 \\
(6,97)\end{array}$ & $\begin{array}{l}365,34 \\
(9,62)\end{array}$ & $\begin{array}{l}348,35 \\
(8,87)\end{array}$ & $\begin{array}{l}365,72 \\
(28,14)\end{array}$ \\
\hline
\end{tabular}

Source: Own calculations: PSLSD 1993; OHS 1999; September LFSs 2002, 2004, 2005; NIDS 2008.

Notes: The data are weighted. A migrant household is a household which reports at least one household member as absent for employment reasons. Remittance values are conditional on remittances being received in migrant households. Standard errors are in parentheses.

A possible explanation for why remittance receipt in households with migrant workers is so low in NIDS (and for why there is such a large mismatch between income transfers and migrant households more generally), may be that migrant workers were underreported in the household questionnaire. Table 7 considers this possibility by reclassifying all African households that receive income transfers as migrant households. With this reclassification, the proportion of African households that contain migrant workers increases to about 25 percent, which is larger than estimates across the earlier years (presented in Table 3 ). The percentage of these migrant households that receive remittances obviously also increases considerably. Nonetheless, only 66 percent of redefined migrant households would be identified as receiving remittance transfers, a measure which remains 
significantly lower than remittance receipt reported in migrant households in earlier years.

Table 7: Reclassifying African migrant households, NIDS 2008

\begin{tabular}{lcc}
\hline & $\begin{array}{c}\text { Percentage of } \\
\text { households with } \\
\text { migrants }\end{array}$ & $\begin{array}{c}\text { Percentage of migrant } \\
\text { households receiving } \\
\text { remittances }\end{array}$ \\
\hline $\begin{array}{l}\text { All households receiving } \\
\text { contributions reclassified as } \\
\text { migrant households }\end{array}$ & 25,47 & 65,87 \\
\hline
\end{tabular}

migrant households

Source: Own calculations, NIDS 2008.

Notes: The data are weighted. Households are reclassified as migrant households if they reported receiving income transfers. Standard errors are in parentheses.

This analysis of the NIDS data therefore suggests a large fall in the extent of remittance receipt among households that report migrant workers as absent household members, and a decline more generally in the proportion of households receiving inter-household transfers. These findings are consistent with those reported in Leibbrandt et al.'s (2010) study of changes in the South African income distribution, where the authors identify a decline in the contribution of remittances to total household income from 1993, and particularly from 2000 to 2008. At the same time, the share of income from social grants steadily increased (Leibbrandt et al., 2010: 26-27). ${ }^{7}$

\section{Concluding comments}

NIDS includes a more comprehensive set of questions on migration and related information than most other nationally representative household surveys in South Africa. The approach to identifying household membership, labour migration and inter-household transfers closely resembles that adopted in the 1993 PSLSD. In contrast to the surveys conducted by Statistics South Africa, individuals can be included as household members even if they are not resident in the household for much of the year, and information is collected on all inter-household transfers, and not only on remittances received from migrant workers.

While the survey questions on household membership, migration and interhousehold transfers are largely comparable, this paper has highlighted a number of differences between estimates generated in NIDS and in the PSLSD. In particular, in NIDS a far smaller proportion of households report non-resident household members; there is a significant decline also in the proportion of household members who are identified as being absent for employment reasons (migrant workers); a smaller share of households report receiving income transfers from individuals who

\footnotetext{
${ }^{7}$ A number of studies using national household survey data for South Africa have found that the receipt and value of remittances is larger in households that do not receive social pensions (Posel 2001, Jensen 2003, Posel, Fairburn and Lund 2006), or that where households "lose" pensioners because of outmigration or mortality, remittance receipt increases (Ranchhod 2009). These results would be consistent with the argument that social grant income crowds out remittance transfers, and this may explain why a fall in remittance receipt is identified in the NIDS data.
} 
are not resident household members; and there is a substantially weaker relationship between the receipt of transfers and households with migrant workers. In comparison to the other households surveys described in the paper (the 1999 OHS and the September rounds of the LFSs from 2002 to 2005), estimates of labour migration, and remittance receipt are also considerably lower in NIDS.

There are also a number of similarities between the NIDS data and other household survey data. Although levels of absence, labour migration and remittance receipt differ markedly in NIDS, the demographic profile of labour migrants and migrants more generally and the value of remittances (conditional upon receipt) are largely consistent or follow consistent trends across the surveys.

If the NIDS data are identifying real changes, then the survey suggests that a far greater share of individuals who are migrating for employment reasons are also settling in destination areas and that the ties between migrant workers and their households of origin are weakening. The collection of data in the next wave of NIDS will help to evaluate whether these are robust trends.

\section{References}

Aliber, M (2003): "Chronic Poverty in South Africa: Incidence, Causes and Policies", World Development, 31(3), $473-490$.

Bekker, S (2001): "Diminishing Returns: Circulatory Migration Linking Cape Town to the Eastern Cape", SA Journal of Demography, 8(1), 1-8.

Bhorat, H and Leibbrandt, M (2001): "Correlates of Vulnerability in the South African Labour Market", in H. Bhorat, M. Leibbrandt, M. Maziya, S. van der Berg and I. Woolard (eds.), Fighting Poverty. Labour Markets and Inequality in South Africa, University of Cape Town Press, Cape Town, 74-106.

Chant, S and McIlwane, C (2009): Geographies of Development in the $21^{\text {st }}$ century. An Introduction to the Global South, Edward Elgar Publishing Limited, Massachusetts.

Collinson M, Kok, P and Garenne, M (2006): Migration and Changing Settlement Patterns. Multilevel Data for Policy [Report 03-04-01], Statistics South Africa, Pretoria.

Collinson, M, Tollman, S and Kahn, K (2007): "Migration, Settlement Change and Health in PostApartheid South Africa: Triangulating Health and Demographic Surveillance with National Census Data", Scandinavian Journal of Public Health, 35(Supplement 69), 77-84.

Jensen, R (2003): "Do Private Transfers 'Displace' the Benefits of Public Transfers? Evidence from South Africa", Journal of Public Economics, 88(1), 89 - 112.

Leibbrandt, M, Woolard, I, Finn, A and Argent, J (2010): "Trends in South African Income Distribution and Poverty Since the Fall of Apartheid", OECD Social, Employment and Migration Working Papers, No. 101.

May, J and Rogerson, C (2000): “The Spatial Context”, in J. May (ed.), Poverty and Inequality in South Africa: Meeting the Challenge, David Philip, Cape Town, 207 - 228.

Posel, D (2001): "How Do Households Work? Migration, the Household and Remittance Behaviour in South Africa", Social Dynamics, 27(1), 165 - 189. 
Posel, D and Casale, D (2003): "What has been Happening to Internal Labour Migration in South Africa, 1993 - 1999?", The South African Journal of Economics, 71(3), 455 - 479.

Posel, D and Casale, D (2006): "Internal Migration and Household Poverty in Post-Apartheid South Africa", in R. Kanbur and H. Bhorat (eds.), Poverty and Policy in Post-Apartheid South Africa, Human Sciences Research Council Press, Pretoria, $351-365$.

Posel, D, Fairburn, J and Lund, F (2006): "Labour Migration and Households: A Reconsideration of the Effects of the Social Pension on Labour Supply in South Africa", Economic Modelling, 23(4), 836 -853 .

Ranchhod, V (2009): "Household Responses to Adverse Income Shocks: Pensioner Out-Migration and Mortality in South Africa", SALDRU Working Papers, No. 35.

Rigg, J (2006): "Evolving Rural-Urban Relations and Livelihoods in Southeast Asia", in C. Tacoli (ed.), The Earthscan Reader in Rural-Urban Linkages, Cromwell Press, London, 68 - 87.

Van der Berg, S, Burger, R, Leibbrandt, M and Mlatsheni, C (2004): "Migration and the Rural-Urban Interface in South Africa: What Can we Learn from Census and Survey Data?", Paper presented at Workshop on Migration and Poverty, Stellenbosch, 4 March 2004. 